\title{
The Toolbox of Methods for Multidirectional Characterization of Dietary Nucleic Acids; Verification for Raw and Processed Food Products
}

\author{
Joanna Cieślewicz ${ }^{1}$ (D) Zuzanna Koziara ${ }^{1}$ (D) Wiktoria Ćwiklińska ${ }^{1} \cdot$ Agnieszka Bartoszek $^{1}$ (D)
}

Received: 3 August 2020 / Accepted: 9 February 2021 / Published online: 3 March 2021

(C) The Author(s) 2021

\begin{abstract}
Currently, the nutritional value of food is associated mainly with components such as proteins, carbohydrates, and lipids. However, another important macromolecules present in many foods are dietary nucleic acids (dietNA), i.e., DNA as well as both coding and non-coding RNAs. In the context of food chemistry and nutrition, dietNA are nowadays vastly neglected. In consequence, there are no dedicated methodologies to characterize dietNA. In this study, using raw or processed meat and plant products as model foodstuffs, we developed a toolbox of methods borrowed from other fields (histology, toxicology, molecular biology) that enable the initial characterization of dietNA as a necessary step on the way to systematic evaluation of their nutritional role. The proposed set of methods embraces (i) paraffin embedding of food samples and their staining to visualize the distribution and variety of dietNA in situ; (ii) comet assay to assess integrity of nuclear DNA with possible detection of DNA damage; (iii) dietNA isolation with and without RNAse digestion to determine the content of both DNA and RNA; (iv) electrophoretic separation of isolates to profile dietNA fragments. Such a combined methodological approach revealed clear differences between dietNA derived from raw and processed food products. We believe that the presented set of methods will encourage the broader research on dietNA to understand their role as a nutritionally relevant food component.
\end{abstract}

Keywords Dietary nucleic acids $\cdot$ Meat and meat products $\cdot$ Edible plants $\cdot$ DNA profiling $\cdot$ Paraffin-embedded food samples

\section{Introduction}

Nucleic acids (NA), deoxyribonucleic acid (DNA), and various forms of ribonucleic acid (RNA) are present in every living cell of animal and plant organisms as well as in microorganisms; therefore, in most foodstuffs consumed by humans, their presence is expected. Next to proteins, fats, vitamins, and carbohydrates, they are a natural component of food products, primarily of those containing cellular structures. In the case of consumption of foods contaminated with, for example, viruses, a certain amount of viral NA, including double-stranded RNA, can be introduced into the human gastrointestinal tract. With fermented foods, a substantial share of yeast and microbial NA is also consumed (Jonas et al. 2001). It thus comes as a surprise, that the current knowledge on the

Agnieszka Bartoszek agnieszka.bartoszek@pg.edu.pl

1 Department of Food Chemistry, Technology and Biotechnology, Faculty of Chemistry, Gdansk University of Technology, 11/12 Narutowicza St., 80-233 Gdansk, Poland exact content of NA in raw and processed food products is vastly limited and only very few studies addressing specifically this subject can be found in scientific literature (Głazowska et al. 2016). Moreover, these publications mainly originate from the past century (Herbel and Montag 1987; Imafidon and Sosulski 1990; Lassek and Montag 1990; Adjei et al. 1995) when technology of NA isolation and determination was much less developed than today and the majority of non-coding RNAs (ncRNA) has not even been discovered.

According to the mentioned past assessments, particularly rich in both types of NA are rapidly growing tissues or those that retained the potential for growth and regeneration, such as raw meat (muscle) and offal, seafood, legumes, and mushrooms (Jonas et al. 2001). Adjei et al. (1995) regarded meat and fish products as rich in NA $\left(1.5-8 \mathrm{mg} \mathrm{g}^{-1}\right)$. In turn, seafood and vegetables such as beans, peas, or lentils and mushrooms contain medium quantities of NA in their tissues $(0.5$ $1.5 \mathrm{mg} \mathrm{g}^{-1}$ ). The remaining vegetables, fruits, cereals, and dairy products contain much lower amounts of NA measured as purines, i.e., up to $0.2 \mathrm{mg} \mathrm{g}^{-1}$ of product (Jonas et al. 2001). It has been estimated that the daily dietary intake of NA ranges from 0.1 to $1 \mathrm{~g}$ person ${ }^{-1}$ per day (Jonas et al. 2001). At the 
same time, it has been suggested that a safe intake of nucleic acids by a human adult is $2 \mathrm{~g}$ per day (Carver and Walker 1995), with a maximum recommended consumption of $4 \mathrm{~g}$ per day of DNA and RNA (Adjei et al. 1995), though it must be emphasized that according to our best knowledge, no reports of human studies dedicated specifically to formulate such recommendations can be found in scientific literature.

In this paper, all NA consumed with food products will be called dietary nucleic acids (dietNA) to differentiate them from endogenous consumer's NA. Although consumers are exposed to dietNA of animal, fungal, microbial, and/or plant origin on a daily basis, the nutritional consequences of this ingestion are poorly understood. The gastrointestinal (GI) tract is the place where dietNA come in contact with epithelium cells that form a barrier for the entrance of foreign, potentially recombinogenic, or regulatory molecules (Schubbert et al. 1998). On one hand, certain dietNA may display invasive properties and pose a risk; on the other hand, it has been demonstrated that dietNA exhibit some beneficial properties on the human and animal organism and GI tissue (Hess and Greenberg 2012). They speed up the recovery after intestinal injury and improve the histological structure of the intestine (Carver and Walker 1995; Carver 1999). They also influence positively the immunological system by modulating its maturation and immune response (Carver 1999; Manzano et al. 2003; Nakamoto et al. 2011). The consumed dietNA and nucleotides have been reported to augment the recovery of the organism after an intense physical activity by improving mitochondrial functions resulting in enhanced adenosine triphosphate (ATP) production and turnover as well as reduction of oxidative stress in skeletal muscles (Xu et al. 2017). Due to their structure and amount in each cell, NA are a rich source of organic nitrogen, phosphorous, and pentose sugars. Although proteins are associated usually with nitrogen metabolism, it is important to notice that an average amino acid contains $1.45 \mathrm{~N}$ atoms, while an average nitrogenous base contains $3.4 \mathrm{~N}$ atoms (adenine, guanine -5 atoms), meaning that each purine and pyrimidine nucleotide provide respectively 3.45 and 1.61 times more nitrogen atoms per molecule, than an average amino acid. Therefore, the postulated involvement of dietNA in several important metabolic pathways comes as no surprise, including those responsible for body temperature maintenance as a result of influencing the mitochondrial function, as well as for anti-fatigue effect (Xu et al. 2017). DietNA can also serve as precursors of important cell signalling and co-enzyme molecules as well as be reused in the very nitrogen-needy de novo NA synthesis and DNA repair. However, consumption of dietNA, at non-physiological levels of purine nucleosides and nucleotides, may result in the increased production of uric acid in the body and its derivatives in serum, which are not neutral to the health status of the consumer (Hess and Greenberg 2012). High levels of these metabolites, especially in the case of certain diseased states, can lead to the formation of uric acid crystals and the subsequent development of the so-called gout (Jonas et al.
2001). Most recently, some studies have also suggested other than nutritional functions of dietNA, namely the regulatory role of ingested ncRNA (Głazowska et al. 2017), which is best evidenced in the case of human milk (Melnik and Schmitz 2017; Jakubek et al. 2020). Maternal milk plays a significant role in infant development by modulating the proper growth and maturation of basic digestion and metabolic functions, due to specific composition of highly nutritional components, especially microRNAs (Doare et al. 2018; Jakubek et al. 2020). Moreover, animal studies suggested the possibility of horizontal transfer of low molecular weight dietNA in vivo from the feed to the cells of mouse intestinal mucosa and further to the bloodstream, which affected gene expression in the animal tissue and consequently could affect the functioning of its body (Zhang et al. 2012; Witwer and Hirschi 2014; Yang et al. 2018). However, this hypothesis at the moment remains rather controversial (Witwer and Zhang 2017).

From the available literature, it is known that raw and processed meat products contain in their cellular structure both nuclei and nucleic acids that have not been degraded by either aging or tenderization processes occurring in the meat after animal death (Adjei et al. 1995) or thermal and culinary treatment. Until now, it has been found that boiling at elevated and atmospheric pressure, frying in deep fat, or microwave treatment retains DNA fragments of plant (Van Der Colff and Podivinsky 2008) or animal origin (Arslan et al. 2006) of sufficient quality and quantity to enable amplification of these fragments with polymerase chain reaction (PCR) techniques. This applies to experiments on both identification of species and amplification of fragments encoding particular proteins, specific to a source material. However, these trials were not designed to determine the content of NA, but only to use them for the specific characterization of the investigated material such as detection of potentially allergenic food additives and contaminations (Herman et al. 2003; Tanabe et al. 2007; Scaravelli et al. 2008), evaluation of food quality and purity (Meyer et al. 1996), addition of genetically modified (GM) organisms (Ferrari et al. 2007), or recombinant DNA stability (Straub et al. 1999). These investigations are thus not truly a source of data on dietNA abundance and composition.

The effects mentioned above suggest that the determination of the quantity and quality of ingested dietNA by humans may be important from the nutritional and general health perspective. In particular, no data are available on the impact of food processing on chemical modifications of dietNA components. Therefore, at the moment, the lack of a reliable source of information makes it difficult to estimate the amount of NA present in food consumed every day, which will with no doubt be influenced by the variety of food sources, multitude of diets, the degree of food processing, etc. Until such results based on dedicated research are available, the nutritional role of dietNA will still not be fully explained. In this paper, we propose a set of methods commonly used in molecular 
biology and histological studies as a new approach to multidirectional dietNA characterization and profiling in terms of both their abundance, distribution, and fragmentation pattern reflecting the degree of degradation in raw and processed foodstuffs. The meat and plant-originated products were used as model food ingredients that can be consumed following a variety of culinary processing.

\section{Materials and Methods}

\section{Chemicals and Biochemicals}

The low melting point (LMP) and normal melting point (NMP) agarose were purchased from Sigma-Aldrich (USA) and Bioline (UK), respectively. The 96\% ethyl alcohol, anhydrous ethyl alcohol, boric acid, and xylene were purchased from POCH (Poland). The sodium chloride, sodium hydroxide, chloroform, ethylenediaminetetraacetic acid (EDTA), Trizma-base, Tris-HCl, dimethyl sulfoxide (DMSO), and sodium dodecyl sulfate (SDS) were from Sigma-Aldrich (USA). In this study, the proteinase $\mathrm{K}$ from Tritirachium album (Blirt S.A. DNA-Gdańsk, Poland) and ribonuclease A (RNase A, EC 3.1.27.5), $100 \mu \mathrm{g} \mathrm{mL}^{-1}$ in 10-mM sodium acetate buffer pH 5.2 from Sigma-Aldrich (USA) were used. For nucleic acid and tissue staining on microscope slides, Hoechst $33342\left(1 \mu \mathrm{L} \mathrm{mL} \mathrm{L}^{-1}\right.$ working solution in water, ThermoScientific, USA), methyl green-pyronin Y (MGP, ready to use solution, Sigma-Aldrich, USA), eosine (Serva), Delafields hematoxyline, and GelRed $(10,000 \times$ concentrated, ImmuniQ, Poland) were used. In comet assays, nucleic acids were stained with SYBR Green (Sigma-Aldrich, USA) $10,000 \times$ diluted in tris-EDTA (TE) buffer $(10-\mathrm{mM}$ Tris$\mathrm{HCl}, 1-\mathrm{mM}$ EDTA, pH 7.5). During nucleic acid agarose gel separation, the DNA size marker M10 kbp with DNA fragments from $200 \mathrm{bp}$ to $10 \mathrm{kbp}$ and $6 \times$ concentrated loading buffer (DNA Ladder, DNA-Gdańsk, Poland) were applied. For isolation of nucleic acids, the DNeasy Blood \& Tissue Kit (Qiagen GmbH, Germany) and the phenol/chloroform/ isoamyl alcohol reagent (25:24:1, v/v/v, Sigma-Aldrich, USA) were used. Additionally, for preparation of paraffinembedded food samples, histological paraffin (Histosec pastilles, Merck, Germany), 4\% formaldehyde solution in phosphate buffer (Mega Herba, Poland), 36-38\% formaldehyde (POCH, Poland), glacial acetic acid (Merck, Germany) and Neo-Mount anhydrous resin for mounting of stained histological samples (Merck, Germany) were used. Water was purified with MilliQ (Millipore) system (Merck, Germany).

\section{Food Samples}

The sirloin meat portions were derived from the single cut of a pork meat, and after slaughter and 24-h maturation period, was bought at a local meat-processing plant that owns a slaughterhouse in the Pomerania region, Poland. The meat came from a domestic pig (Sus scrofa f. domestica), females 6 months old, fed with bio fit concentrate, grain, triticale, and their mixtures. Each pork loin was divided into samples for culinary processing, and processed on the same day. The chicken meat portions, derived from single broiler, after slaughter and 48 -h cold storage $\left(4^{\circ} \mathrm{C}\right)$ were obtained from the local village in the Pomerania region, Poland. Green bean (Phaseolus vulgaris) $(0.5 \mathrm{~kg})$, kohlrabi (Brassica oleracea var. gongylodes) (one piece), potato (Solanum tuberosum) $(0.5 \mathrm{~kg})$, and celery (Apium graveolens var. dulce) (one bunch of stalks) were bought at the local supermarket in the Pomerania region, Poland. All samples were stored at $-80^{\circ} \mathrm{C}$ until used. Industrial meat products included steamed white sausage (one piece) and baked meat pate $(0.5 \mathrm{~kg})$ from the regular portfolio of Meat Company Nowak, Jankowo, Northern Poland.

\section{Meat Sample Preparation}

In this study, raw chicken meat and raw or home-processed pork (sirloin) or industrial pork meat products were used. Typical culinary home treatments or those applied by the food industry were used to obtain samples of pork processed meat. The home-processed pork was basically suitable for human consumption, but without addition of salt or spices, unless indicated otherwise. Three types of thermal treatments were applied to receive a product suitable for human consumption. A pork slice $1.5 \mathrm{~cm}$ thick was either boiled for $60 \mathrm{~min}$ in $1 \mathrm{~L}$ of distilled water without salt addition or grilled in a microwave oven (Bartscher GmbH, Germany) using the full power of the heater $(1000 \mathrm{~W})$ for $20 \mathrm{~min}$ on each side of a slice.

\section{Preparation of Paraffin-Embedded Meat Samples}

The nuclei and nucleic acids in meat tissue were visualized by fluorescent staining of paraffin-embedded meat sections. Directly after culinary treatment, from each meat sample, the fragments with dimensions of $0.5 \times 1.0 \times 2.0 \mathrm{~cm}(\mathrm{H} \times \mathrm{W} \times \mathrm{L})$ (at least 5-10 portions per sample) were cut out. Raw meat was fixed in $4 \%(\mathrm{v} / \mathrm{v})$ formaldehyde in phosphate buffer for 24 $\mathrm{h}$, then rinsed under running water for $6 \mathrm{~h}$ and transferred to $50 \%$ ethanol for $1 \mathrm{~h}$. From the sausage slices and from meat pate, fragments with dimensions of $0.5 \times 1.0 \times 2.0 \mathrm{~cm}(\mathrm{H} \times \mathrm{W}$ $\times$ L) were cut out. All meat samples were dehydrated initially with $60 \%(\mathrm{v} / \mathrm{v})$ ethanol aqueous solution for about $1 \mathrm{~h}$. Thereafter, the meat samples were transferred to a series of staining chambers containing increasing concentrations of ethanol $(70 \%, 80 \%, 96 \% \mathrm{v} / \mathrm{v}$ of ethanol) and finally absolute ethanol. In each solution, the meat samples were kept for about $1 \mathrm{~h}$. In the case of meat samples for which two washing steps in absolute alcohol were not enough to enable their 
saturation with xylene in whole volume, one or two additional washing steps (in total 3 or 4 times) in absolute ethanol were performed before the saturation with xylene. After dehydration, the samples were submerged for $10 \mathrm{~min}$ in a mixture of xylene:absolute ethanol $(1: 1 \mathrm{v} / \mathrm{v})$ to pre-saturate the tissues with xylene, then placed in pure xylene to complete the saturation of the tissue. The xylene-saturated samples were characterized by a glassy structure within the whole volume. Finally, the meat samples were placed in a mixture of xylene and paraffin 9:1 (v/v) for $1 \mathrm{~h}$ and transferred to a liquid histological paraffin (Histosec pastilles, Merck, Germany) thermostated at $58{ }^{\circ} \mathrm{C}$ in a thermostat (Binder $\mathrm{GmbH}$, Germany), where they remained for $24 \mathrm{~h}$. This step allowed the saturation of tissue with paraffin. The paraffin-saturated samples were placed in histological metal molds previously filled with deaerated liquid paraffin. The paraffin was deaerated by immersing red-hot tweezers in it until the air bubbles were not visible. The blocks were allowed to solidify at room temperature for $24 \mathrm{~h}$. The solid paraffin blocks were removed from the histological molds, placed in the arm of manual rotary microtome (SM 2000 M, Jung Heidelberg, Germany), and cut into $7-\mu \mathrm{m}$-thick slices. The obtained paraffin-embedded tissue sections were placed on a water surface prewarmed to $37^{\circ} \mathrm{C}$, where the cuts were straightened and transferred on the surface of clean, defatted microscope glass slides. The slices were left on the heated surface $\left(37^{\circ} \mathrm{C}\right)$ until fully dried and attached to glass.

\section{Preparation of Paraffin-Embedded Plant Samples}

Paraffin-embedded plant samples were prepared according to the procedure proposed by Weigel and Glazebrook (2008) with modifications. Small pieces of plant samples were submerged in formalin-acetic acid-alcohol fixative (48\% ethyl alcohol, 3.7\% formaldehyde, 5\% glacial acetic acid, FAA) in beakers then placed in a desiccator. The vacuum was turned on and the reduced pressure was maintained for $15 \mathrm{~min}$. The procedure was repeated twice. Samples were placed in a new portion of FAA and incubated for $4 \mathrm{~h}$. After fixation, all plant samples were dehydrated initially with $60 \%(\mathrm{v} / \mathrm{v})$ ethanol aqueous solution for about $30 \mathrm{~min}$. Thereafter, the plant samples were transferred to a series of staining chambers containing increasing concentrations of ethanol $(70 \%, 80 \%, 96 \% \mathrm{v} / \mathrm{v})$ and finally absolute ethanol (twice). In each solution, the plant samples were kept for about $30 \mathrm{~min}$ (except for the first portion of absolute ethanol in which the samples were kept for 1 h). After dehydration, the samples were submerged in solutions with increasing xylene concentration relative to absolute ethyl alcohol $(1: 3,1: 1,3: 1 \mathrm{v} / \mathrm{v})$. In each solution, the tissues were kept for $30 \mathrm{~min}$. The tissues were then rinsed twice in pure xylene, each time for $1 \mathrm{~h}$. Further preparation stages were proceeded as described for meat samples.

\section{Basic Tissue Staining}

The raw and culinary treated meat tissue sections as well as fragments of plant were stained with hematoxylin and eosin to visualize the overall tissue structures. These dyes are watersoluble; therefore, to enable the staining of meat and plant tissue, it was necessary to dewax and rehydrate paraffinembedded meat and plant slides by two washes in xylene ( 2 min per slide) and in a series of solutions with decreasing ethanol concentration (absolute alcohol - twice, 96\%, 80\%, $70 \%, 60 \%, 50 \% \mathrm{v} / \mathrm{v}$, water $-2 \mathrm{~min}$ in each). Staining in hematoxylin lasted up to $45 \mathrm{~s}$, or until the nuclei became visible as purple or dark blue spots. The excess dye was removed by washing the microscope slides under a gentle stream of tap water for about $20 \mathrm{~min}$. After brief immersion in distilled water, the slides were transferred to $70 \%$ ethanolic eosin solution for about $10 \mathrm{~s}$. The time of exposure of the sample to the dye solution was dependent on the concentration of the dye, and lasted until the cytoplasm turned red-orange colored. Subsequently, a brief immersion of stained microscope slides in a series of increasing ethanol concentration solutions for dehydration (from $70 \%$ up to absolute alcohol) was performed. The ethanol present in tissue sections was removed by washing in two portions of xylene, for 2 and 5 min, respectively. Dehydrated tissue sections were coated with a drop of anhydrous Neo-Mount resin for closing and covered with a cover slip. After molting, the microscope slides were analyzed using a light Olympus BX 60 microscope, under $\times 10$ and $\times 20$ magnification.

\section{Fluorescent Staining of Nucleic Acids}

The meat and plant sections were stained with DNA and RNA selective fluorescent dyes: Hoechst 33342 and MGP mixture, which should enable the staining of deoxyribonucleic acid in nuclei in purple-bluish (methyl green) and the ribonucleic acid and cell plasma in red (pyronin Y). Hoechst 33342 and the MGP mix were applied on separate microscope slides. Due to the aqueous nature of these dyes, it was necessary to dewax and rehydrate the meat and plant tissue sections as described before. After a short rinse in distilled water, 1-2 drops of dye working solution was applied on the surface of the tissue for 10 and $30 \mathrm{~min}$ for Hoechst 33342 and MGP, respectively. From that point, the microscope slides were protected from light. After staining, the slides were washed in deionized water for $1 \mathrm{~min}$, mounted with a drop of anhydrous resin Neo-Mount, covered with a cover slip, and immediately analyzed under fluorescent light using Olympus BX 60 microscope, applying $\times 10$ and $\times 20$ magnifications. Staining with a methyl green and pyronin Y dye mixture was done by green, red, and blue fluorescent channel overlay, according to Li et al. (2002). 


\section{DNA Integrity in Meat Samples by Comet Assay}

The comet assay protocol used to assess DNA fragmentation in cells of raw and culinary treated meat samples was adapted from European Norm EN-13784, with modifications. Briefly, a suspension of nuclei from deep frozen meat samples was prepared as follows: about $1 \mathrm{~g}$ of frozen material was cut or scraped off with a sharp scalpel, cut into thin slices, and transferred to a beaker containing $5 \mathrm{~mL}$ of cold phosphate-buffered saline solution (PBS). The suspended meat flakes were stirred using a magnetic stirrer (500 rpm) for $5 \mathrm{~min}$ on an ice bath. Then, the suspension was filtered through gauze with a pore size of about $500 \mu \mathrm{m}$, to remove the tissue particulates. The filtrate was allowed to settle on ice for about $5 \mathrm{~min}$ and was used as a cell extract. The cell extract $(20 \mu \mathrm{L})$ was mixed with $200 \mu \mathrm{L}$ of melted $0.8 \%(\mathrm{w} / \mathrm{v})$ LMP agarose in PBS thermostated at $45{ }^{\circ} \mathrm{C}$. The suspension $(35 \mu \mathrm{L})$ was applied dropwise on a microscope slides pre-coated with NMP agarose $1 \%(\mathrm{w} / \mathrm{v})$ in distilled water, immediately covered with a cover slip, and allowed to solidify on ice for $5 \mathrm{~min}$. The cover slips were carefully removed and agarose embedded nuclei were lysed for $10 \mathrm{~min}$ at room temperature in Tris-borateEDTA buffer (TBE; $1 \times$ concentrated) containing $2.5 \%(\mathrm{w} / \mathrm{v})$ SDS. The slides were transferred to electrophoresis apparatus (Bio-Rad, USA) filled with $1 \times$ TBE buffer and topped with 2 $4 \mathrm{~mm}$ of the buffer layer. Under these conditions, the chromatin unwinding stage was carried out for $5 \mathrm{~min}$. Electrophoresis was carried out in the same $1 \times$ TBE buffer for 2 min at $2 \mathrm{~V}$ $\mathrm{cm}^{-1}$, at room temperature. Then, the microscope slides were rinsed with water for $5 \mathrm{~min}$ and air-dried. The nuclei present on microscope slides were stained with $10,000 \times$ diluted SybrGreen dye solution for $30 \mathrm{~min}$, rinsed for $10-15 \mathrm{~min}$ in water, and covered with cover slips. The DNA fragmentation (DNA comets) was observed under a fluorescence microscope coupled with a camera for recording of images. Comets were analyzed at $\times 50$ magnification using METAFER 4 (Metasystems, Germany) software. The assay was performed in four replicates for each meat sample, and on each slide 100 (or all when there was less than 100 objects), consecutive comets were counted.

\section{DNA Integrity in Plant Samples by Comet Assay}

The comet assay protocol used to assess DNA fragmentation in plant cells was adapted from Pourrut et al. (2014) with modifications. Briefly, a suspension of nuclei from deep frozen plant samples was prepared as follows: about $450 \mathrm{mg}$ of frozen material was placed in Petri dish (kept on ice) containing $1.5 \mathrm{~mL}$ of cold $400-\mathrm{mM}$ Tris- $\mathrm{HCl}$ buffer $(\mathrm{pH}=7.5)$. The tissues were vigorously chopped with a razor for $30 \mathrm{~s}$. The Petri dish was then kept on ice for $5 \mathrm{~min}$. Then, the suspension was filtered through gauze with a pore size of about $500 \mu \mathrm{m}$, to remove the tissue particulates, and the obtained cell extract was stored on ice. The cell extract $(90 \mu \mathrm{L})$ was mixed with $150 \mu \mathrm{L}$ of melted $1 \%(\mathrm{w} / \mathrm{v})$ LMP agarose in PBS thermostated at $45^{\circ} \mathrm{C}$. The suspension $(80 \mu \mathrm{L})$ was applied dropwise on a microscope slides pre-coated with NMP agarose $1 \%(\mathrm{w} / \mathrm{v})$ in distilled water, immediately covered with a cover slip, and allowed to solidify on ice for $5 \mathrm{~min}$. The cover slips were carefully removed and the slides were transferred to electrophoresis apparatus (Bio-Rad, USA) filled with cold electrophoretic buffer ( $300 \mathrm{mM} \mathrm{NaOH}, 1 \mathrm{mM} \mathrm{Na}_{2}$ EDTA, $\mathrm{pH}>13$ ) and topped with 2-4 $\mathrm{mm}$ of the buffer layer. Under these conditions, the chromatin unwinding stage was carried out for $15 \mathrm{~min}$. Electrophoresis was carried out in the same buffer for $5 \mathrm{~min}\left(300 \mathrm{~mA}, 0.72 \mathrm{~V} / \mathrm{cm}, 4^{\circ} \mathrm{C}\right)$. Then, the microscope slides were rinsed three times with $400-\mathrm{mM}$ Tris-HCl buffer for $5 \mathrm{~min}$ and air-dried. The nucleic stained and analysis stages were performed analogously to meat samples, but at $\times 100$ magnification.

\section{DNA Isolation from Meat Samples}

Raw and processed meat samples were used for the isolation of nucleic acids by phenol/chloroform/isoamyl alcohol $(25: 24: 1, v / v / v)$ solvent extraction method. For all meat samples, the DNA isolation with and without the RNase A $\left(100 \mu \mathrm{g} \mathrm{mL}^{-1}\right)$ addition was performed. The tissue was scraped with a scalpel from frozen meat sample. About $25 \mathrm{mg}$ of meat sample was weighed, placed in a $1.5 \mathrm{-mL}$ centrifuge tube, and combined with $200 \mu \mathrm{L}$ of lysis buffer (20$\mathrm{mM}$ Tris $\mathrm{pH}$ 8.0, 20-mM NaCl, 20-mM EDTA pH 8.0, $1 \%$ (w/v) SDS, $600 \mu \mathrm{g} \mathrm{mL}^{-1}$ proteinase $\mathrm{K}$ ). The sample was homogenized with a hand homogenizer (Pellet Mixer, VWR, USA) and incubated in a dry heating bath (QBD4 Grant, UK) for $1.5 \mathrm{~h}$ at $37^{\circ} \mathrm{C}$, then $1.5 \mathrm{~h}$ at $56^{\circ} \mathrm{C}$ or until completely digested (no floating particles visible), but not longer than for $6 \mathrm{~h}$. After incubation, the lysate was diluted 1:1 (v/v) with dilution buffer (150-mM NaCl, 5-mM EDTA). Phenol/chloroform/isoamyl alcohol $(25: 24: 1, \mathrm{v} / \mathrm{v} / \mathrm{v})$ in an aliquot of $1: 1$ $(\mathrm{v} / \mathrm{v})$ was added to the sample and it was thoroughly shaken for about $30 \mathrm{~s}$ on a laboratory shaker (IKA Vortex, China). The phases were separated by centrifugation for $2 \mathrm{~min}$ at 13,000 rpm with Eppendorf centrifuge (model $5415 \mathrm{R}$, Germany) at room temperature. The aqueous phase (top) was transferred to a new $1.5-\mathrm{mL}$ centrifuge tube, extracted with chloroform 1:1 (v/v) and thoroughly vortexed for a few seconds. It was again centrifuged for $2 \mathrm{~min}$ at 13,000 rpm with Eppendorf centrifuge (model 5415 R, Germany) at room temperature. The separated aqueous phase was collected into a new $1.5-\mathrm{mL}$ centrifuge tube, combined with $5-\mathrm{M} \mathrm{NaCl}$, to reach the final concentration of $250-\mathrm{mM} \mathrm{NaCl}$. The resultant solution was mixed thoroughly. Two volumes of $100 \%$ ethanol were added and the sample was kept overnight at $4{ }^{\circ} \mathrm{C}$. The precipitated DNA was collected by centrifugation for $30 \mathrm{~min}$ at $13,000 \mathrm{rpm}$ at $4{ }^{\circ} \mathrm{C}$ (Eppendorf centrifuge, model 
5415 R, Germany). The obtained supernatant was discarded; the precipitate was washed with cold $70 \%(\mathrm{v} / \mathrm{v})$ ethanol and centrifuged for $10 \mathrm{~min}$ at $13,000 \mathrm{rpm}$ at $4{ }^{\circ} \mathrm{C}$. The supernatant was carefully aspirated and discarded. The precipitate was airdried and dissolved in TE buffer (10-mM Tris, $\mathrm{pH}$ 8.0, 1-mM EDTA) and kept at $4{ }^{\circ} \mathrm{C}$ for further analysis or at $-20^{\circ} \mathrm{C}$ for long-term storage.

\section{Profiling of Isolated Nucleic Acids}

Qualitative analysis of the isolated nucleic acids was performed using spectrophotometric and electrophoretic techniques. Determination of the presence of RNA in the samples was performed by comparing the fragmentation profile of isolated nucleic acid isolated with and without of RNase A addition. The concentration and purity of isolated nucleic acids were determined using NanoDrop 2000 C spectrophotometer (Thermo Scientific, USA). The isolated nucleic acids were separated either by agarose gel (OmniPAGE Electrophoresis System VS20 DGGE, Bio-Rad Cleaver Scientific Ltd) or by capillary electrophoresis (QIAxcel Advanced, Qiagen $\mathrm{GmbH}$, Germany). Agarose electrophoresis was performed in a $1 \%$ $(\mathrm{w} / \mathrm{v})$ agarose gel prepared in $1 \times$ TBE buffer $(89-\mathrm{mM}$ Trizma-Base, 89-mM boric acid, 0.5-mM EDTA, $\mathrm{pH}$ 8.3) with $2 \mu \mathrm{L}$ of ready to use DNA GelRed dye for $6.5 \times 11.5 \times$ $1.0 \mathrm{~cm}$ agarose gel. A M10 kbp DNA fragment marker was used. The separation was performed at room temperature, at a voltage of $100 \mathrm{~V}$ for $1.5 \mathrm{~h}$. The QIAxcel High Resolution DNA cartridge, the QX Alignment Marker 15 bp size marker and QX DNA Size Marker 250 bp - 8 kbp v 2.0 (Qiagen $\mathrm{GmbH}$, Germany) supplemented with $10 \mathrm{kbp}$ and $20 \mathrm{kbp}$ DNA fragments (NoLimits DNA Fragments, ThermoFischer Scientific, USA) were used for capillary electrophoresis. The separation was performed by the OM1200 method, available on the QIAxcel Advanced device. The samples of isolated nucleic acids were analyzed without additional dilutions. The nucleic acid profiles were analyzed with QIAxcel ScreenGel software.

\section{Results}

As outlined in "Introduction," the abundance, profile, and nutritional functions of dietNA have hardly been studied, although these macromolecules occur in food products equally frequently as proteins, polysaccharides, or fats. One of the reasons of this state of art could be the lack of dedicated methods of dietNA characterization in scientific literature. Here, using raw or processed meat products and raw edible plant parts as model foodstuffs, we made an attempt to develop a toolbox of methods, borrowed from other fields (histology, toxicology, molecular biology) that could enable the initial quantitative and qualitative assessment of dietNA prior to systematic evaluation of their nutritional significance.

\section{Distribution of Nucleic Acids in Tested Meat and Plant Samples}

To visualize and simultaneously compare tissue structure and cellular distribution, types, and forms of dietNA in raw or processed meat and raw plant samples, we employed different ways of food tissue staining that are routinely used in the microscopic examination of histological sections embedded in paraffin blocks. The representative images obtained for raw as well as for processed food samples are shown in Figs. 1 and 2. Regardless of stain type, in most meat samples, the muscle fibers or their transverse sections are clearly seen (Fig. 1a-c), including the pate samples that were prepared from finely minced meat (Fig. 1d). The multinucleate nature of myocytes with nuclei located at the cell surface is also revealed. A particularly large amount of nuclear genetic material is noticeable in hepatocytes building chicken liver (Fig. 2b). In the case of bean seeds (Fig. 2a), the cell nuclei are significantly larger and occupy the major part of the cell. This is not surprising as legumes contain about 100 times more DNA than animals. However, other plant samples proved not suitable for paraffin block technique. It was not possible to prepare good quality microscope slides from raw edible parts of kohlrabi, potato, celery, or champignons. In addition, polysaccharide containing cellular structures, especially mushroom chitin, bound non-specifically NA detecting dyes and thereby prevented the observation of distribution of cell nuclei (data not shown).

In the case of NA, hematoxylin being a positively charged dye gives purple color to negatively charged cellular structures such as phosphate groups of polynucleotide backbone. Eosin is an anionic dye, thus enhancing color of positively charged cell structures, which are mostly cytoplasm proteins. Owing to this dual staining, it can be observed that the thermal treatment increases tissue compactness by shrinking the connective tissue volume and thereby reducing endomysium thickness within muscle fibers in the pork meat tissue (Fig. 1a compared to Fig. 1b and c). The hematoxylin-eosin treatment revealed also the presence of cell nuclei which are visible as dark spots and seem not affected by the changes of meat structure due to thermal treatment. However, MGP (methyl green and pyronin $\mathrm{Y}$ dye mixture) and especially Hoechst 33342 dye, a popular cell-permeant nuclear counterstain that emits blue fluorescence when bound to dsDNA, enabled truly effective visualization of nuclei in all analyzed samples (Figs. 1 and 2, panels as described in figure captions). Fluorescent staining ensured a clear distinction and actual confirmation of the presence of cell nuclei in all raw and processed meat samples, as well as in the case of bean seeds. Staining with MGP, according to Li et al. (2002), should enable a clear distinction 


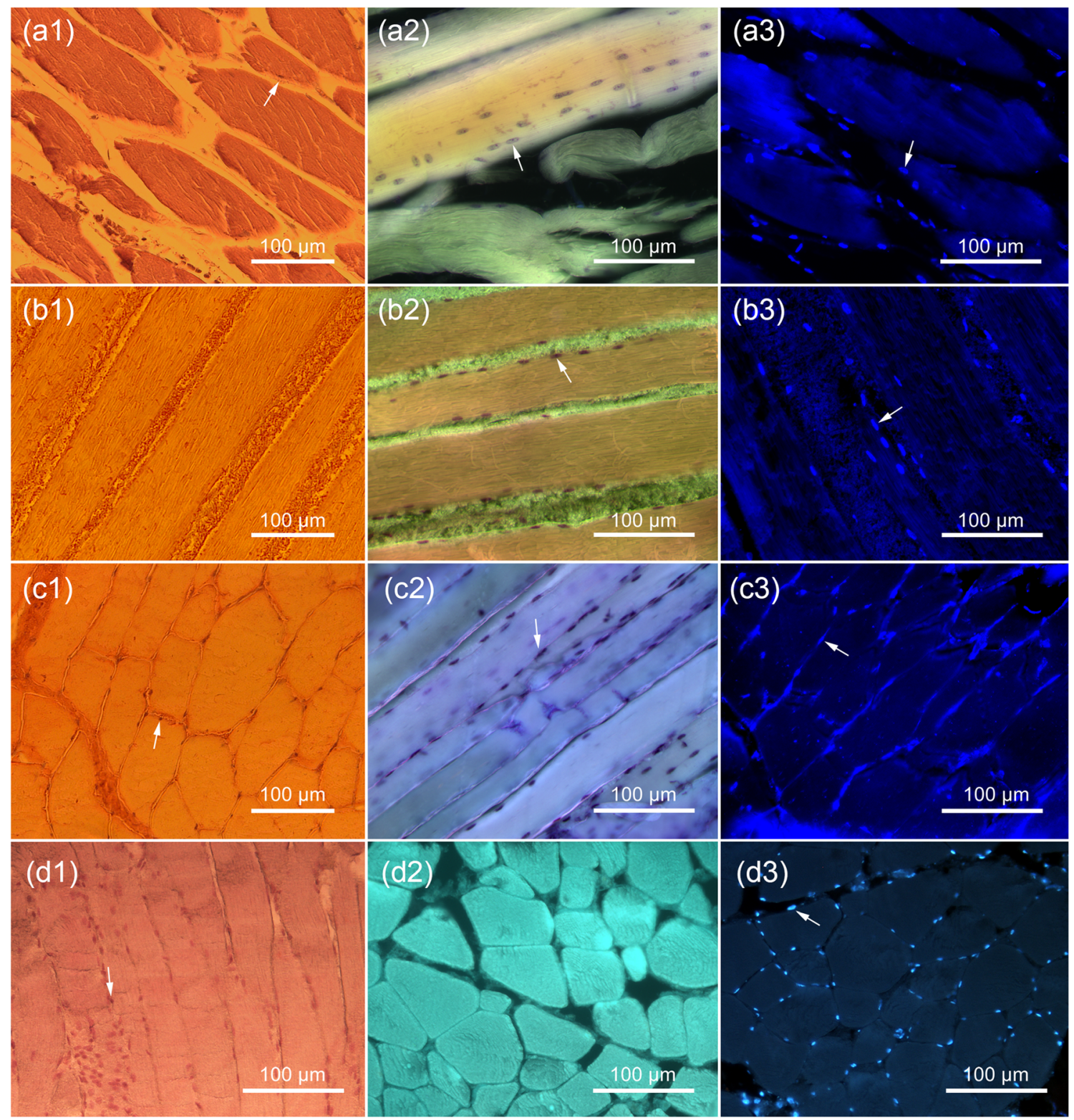

Fig. 1 Microscope images of stained paraffin-embedded raw or culinary treated pork sirloin samples. (a1)-(a3) raw meat samples, (b1)-(b3) boiled in water meat samples, (c1)-(c3) grilled meat samples, (d1)-(d3) meat pate samples. The following methods of staining were applied: (a1),

of the nuclei present in the tissues, better differentiation of various muscle structures, but also RNA detection. The latter type of dietNA was however not detected, while DNA apparently was contained only in nuclei.

\section{Integrity of Nucleic Acids in Tested Meat and Plant Samples}

In contrast to living organism, it can be expected that in raw foods (meat after slaughter or plants in hemibiosis) and especially after thermal processing, cellular DNA protective barriers are not fully operational; thus, dietNA are no longer (b1), (c1), (d1) basic staining with hematoxylin and eosin; (a2), (b2), (c2), (d2) DNA/RNA specific staining with MGP dye; (a3), (b3), (c3), (d3) DNA specific Hoechst 33342 fluorescent staining. Arrows indicate exemplary stained nuclei

protected against oxidative damage. In addition, if not inactivated by culinary treatment, endogenous nucleases may attack dietNA with the result of sugar-phosphate backbone fragmentation until the total degradation, should time and storing conditions allow their activity. In toxicological research, the detection of DNA degradation by single-cell gel electrophoresis, so-called comet assay, is a standard approach to evaluate genotoxicity of environmental exposure. In food research, such evaluations are not common. Nonetheless, also in this field, comet assay has been successfully employed to monitor dietDNA damage arising in food products exposed to ionizing radiation to prolong their shelf life (Cedra 1998; 
Fig. 2 Microscope images of stained paraffin-embedded green bean and raw chicken meat samples. (a1)-(a2) green bean samples, (b1)-(b2) chicken liver samples, (c1)-(c2) chicken breast samples, (d1)-(d2) chicken leg samples. The following methods of staining were applied: (a1), (b1), (c1), (d1) basic staining with hematoxylin and eosin; (a2), (b2), (c2), (d2) DNA specific Hoechst 33342 fluorescent staining. Arrows indicate exemplary stained nuclei

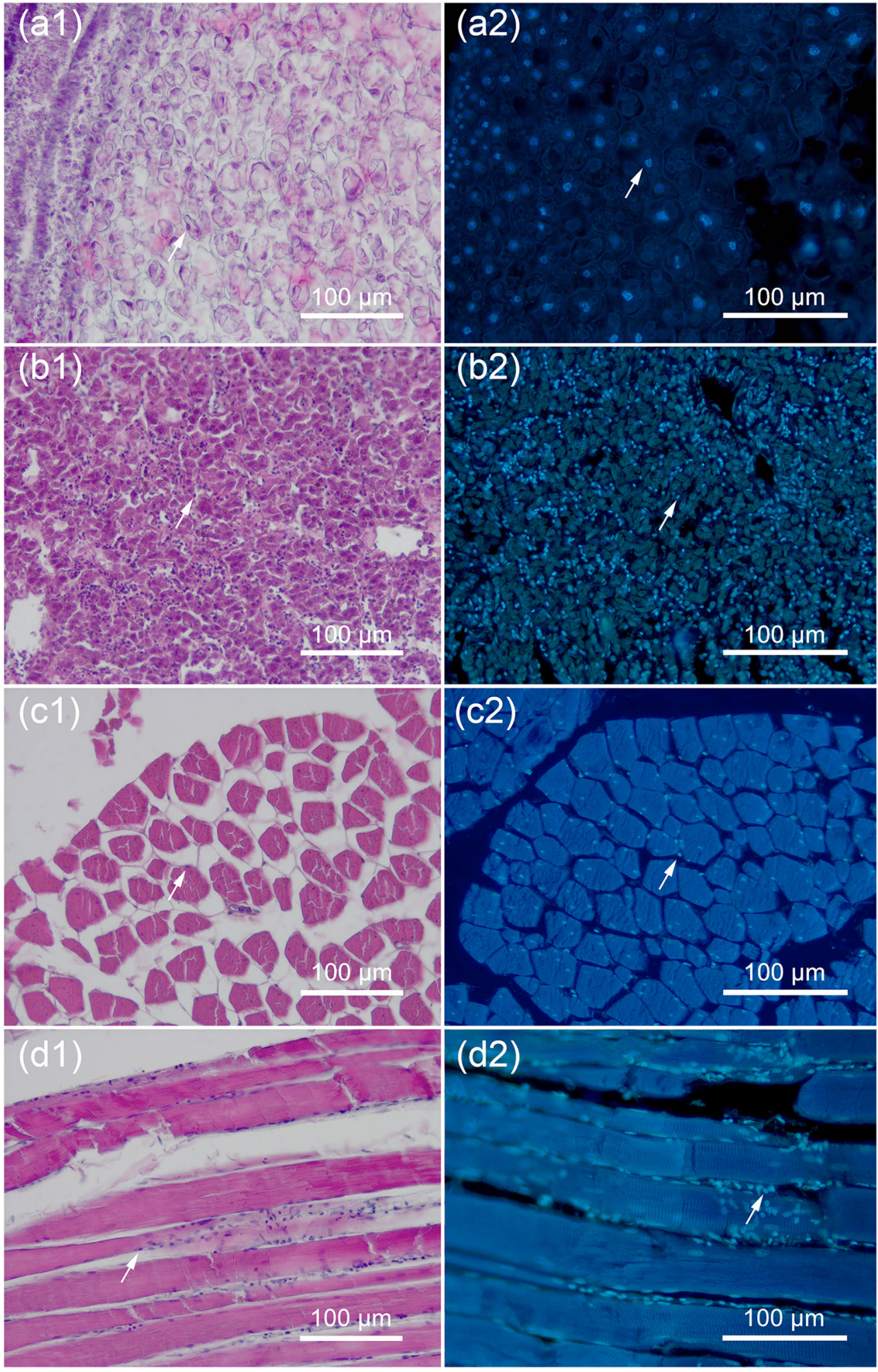

Marín-Huachaca et al. 2005; Khan and Khan 2008). The paraffin block technique showed that all examined food samples contained nuclei, a prerequisite for the use of comet assay. Since this technique detects nuclear DNA fragmentation regardless of cause, we presumed that it may be suitable also to track down changes in dietDNA integrity that could be induced either by endogenous enzymes or chemical insult (mostly oxidation of nucleobases) during culinary processing. Two parameters were determined, percentage of DNA in "tail" informing what portion of nuclear DNA attained the size 
allowing to leave the nucleus and "tail length" that reflects the degree of degradation since the shorter fragments are the farther they migrate during electrophoresis. Figures 3 and 4 present the exemplary microscope images of comets-where comet heads correspond to nuclei while comet tails are built of fragmented DNA — obtained for meat and plant samples.

Figure $3 \mathrm{a}-\mathrm{c}$ shows photographs of representative comets obtained for raw, boiled, and grilled pork meat samples, while Fig. $3 \mathrm{~d}$ illustrates the comparison between the percentage of DNA in the tail and the tail length. The shape of comets obtained for raw meat myocytes (Fig. 3a) suggests some degradation of DNA; however, the fragments must be large as the comet tails are short and not detached from heads. This type of degradation most probably is a result of enzymatic hydrolysis of genomic DNA by endogenous nucleases that may be still active in raw meat. The boiled pork meat sample showed hardly any comet tails characteristic for degraded polynucleotides, but mainly genomic material contained in oval-shaped compact nuclei (Fig. 3b). Even if occurring, the tails were very short and contained little DNA (Fig. 3d); the percentage of DNA in the tail was not higher than $10 \%(8.65 \%)$, and tail length did not reach $50 \mu \mathrm{m}(27.71 \mu \mathrm{m}$ on avarage). There are two explanations to this result; either such a thermal treatment caused no DNA damage while completely blocked endonucleolytic activities or chromatin in nuclei became so compact that the DNA fragments could not migrate during electrophoresis. The observations made for grilled meat rather support the latter explanation. The nuclei examined in grilled meat were characterized by very long tails, detached from heads (Fig. 3c). The tail length was significantly greater than in raw or boiled meat samples, which suggests higher level of DNA fragmentation (Fig. 3d). Indeed, the relationship between the percentage of DNA in the tail and the tail length of comets determined for nuclei isolated from the raw and grilled meat samples is inverse. In the case of raw meat, over half of DNA is found in the tails (53.20\%) that are of 92- $\mu \mathrm{m}$ average length. The grilled meat sample showed lower percentage of DNA in tails (around 30\%), but the mean length of tails was greater than $400 \mu \mathrm{m}$. Such a substantial DNA degradation caused by direct high temperature treatment most probably results from chemical modifications which are converted into strand brakes under alkaline conditions of the comet assay; a phenomenon broadly documented for cells exposed to genotoxins (Delincée and Pool-Zobel 1998; Yao and Zhong 2005).

In the case of raw chicken breast (Fig. 4c), the level of DNA damage is similar to raw pork meat (about $50 \%$ of DNA in comet tails), but the mean length of the comet tails is slightly higher (above $100 \mu \mathrm{m}$ ). The strongest fragmentation of DNA could be seen in the raw chicken liver sample (Fig. 4d), where the degradation was so extensive that comet heads were not visible, and all genetic material is in the tails. Such a large degree of DNA fragmentation in this tissue can be explained by its function. Hepatocytes are characterized by
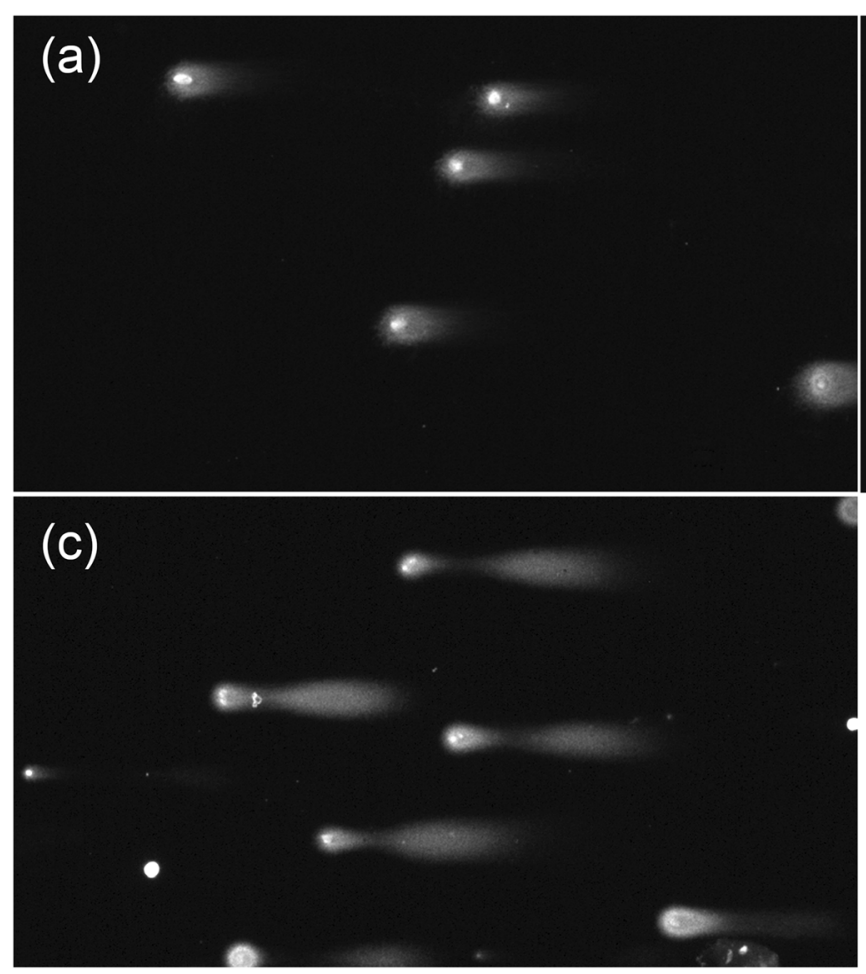

Fig. 3 DNA fragmentation detected by comet assay with SybrGreen staining of nuclei of cells in raw (a), boiled in water (b), and grilled (c) pork sirloin. Graph (d) presents the comparison of comet assay results

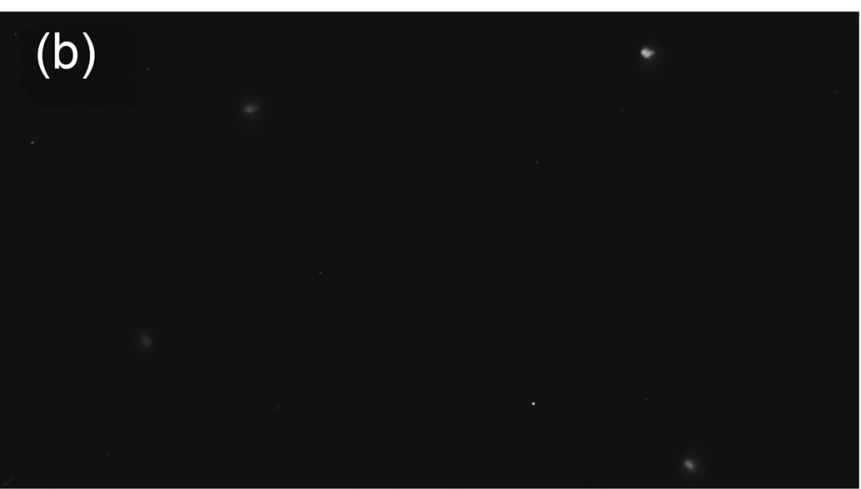

(d)

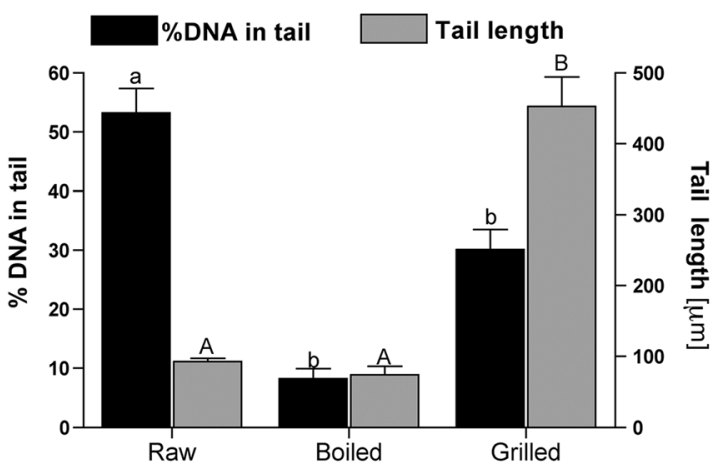

expressed either as \%DNA in tail or the tail length. The statistical analysis was performed by one-way ANOVA with Tukey's multiple comparison test; A vs. B and a vs. b vs. c refer to the level of significance $p<0.01$ 
Fig. 4 DNA fragmentation detected by comet assay with SybrGreen staining of nuclei of cells in green bean (a), potato tuber (b), chicken breast meat (c), and chicken liver (d). Graph (e) presents the comparison of comet assay results expressed as either $\%$ DNA in tail or the tail length; the values are mean \pm SD from three independent experiments carried out for the same food product sample
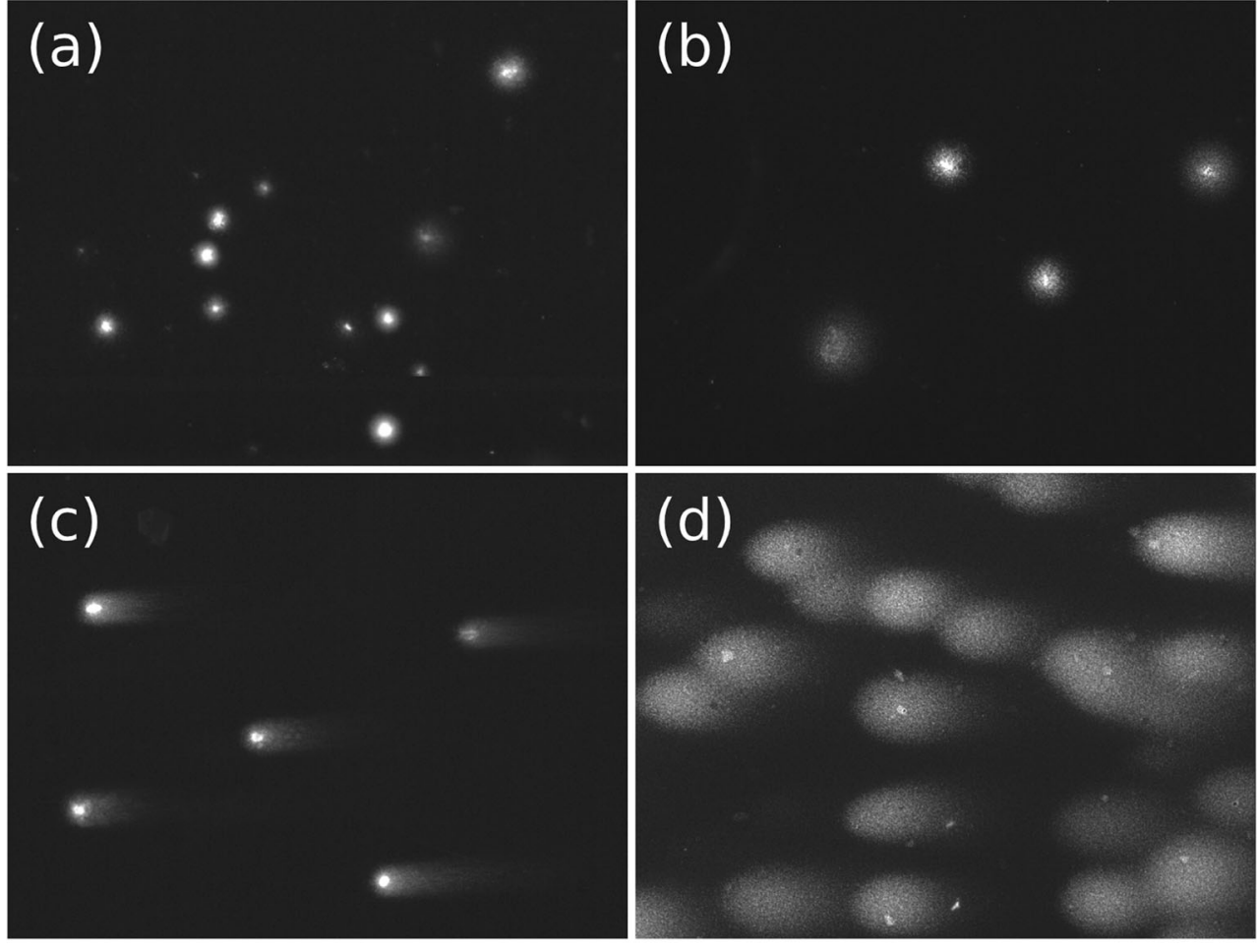

(e)
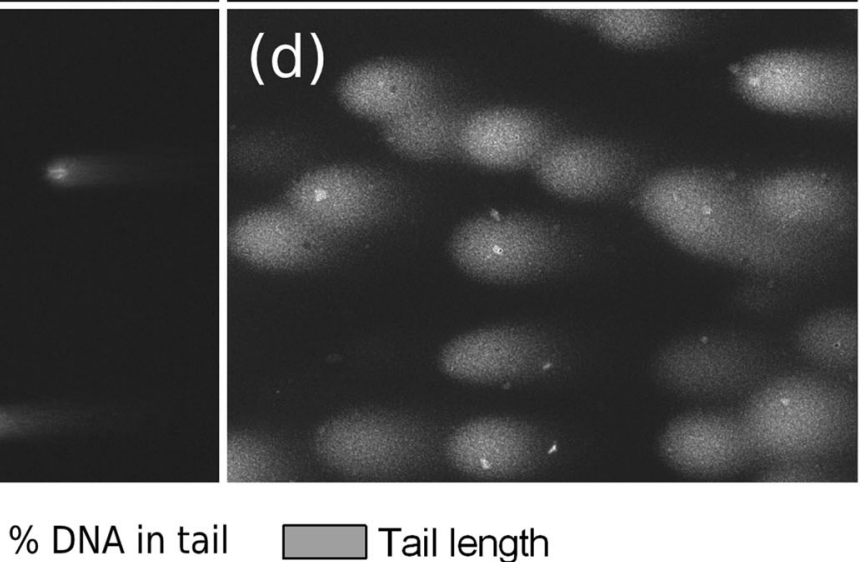

A in tail length

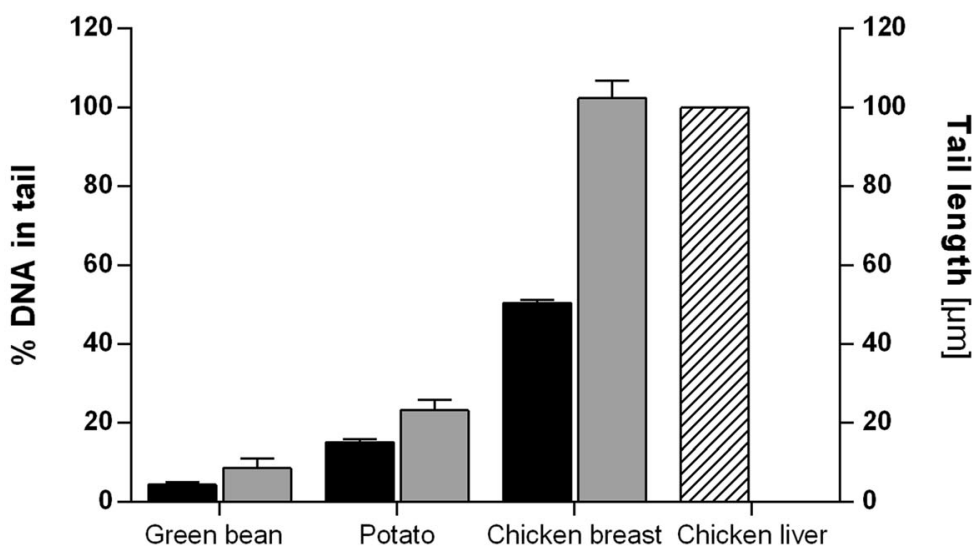

the high rate of transcriptional activity and this may cause their chromatin more liable to nucleolytic hydrolysis. Moreover, the liver is an organ responsible for the detoxification of the body, and therefore its cells are constantly exposed to harmful substances that can damage nucleic acids, despite substantial regeneration capabilities.

Raw plant samples turned out to be the most difficult to be analyzed by comet assay, since the needed separation into individual cells was very inefficient. In successful cases, the degree of fragmentation of genomic DNA was much lower than in meat samples and the percentage of DNA in tail varied from $4 \%$ in bean to $18 \%$ in potato (Fig. $4 a, b$, and e). Plants after harvest are in a state of hemibiosis, when their metabolic processes are not as strongly disturbed as in the case of animal tissues after slaughter, and perhaps this is why the nucleic acids were less vulnerable to degradation.

\section{DNA Isolation from Meat Samples}

The quantitative NA isolation from raw and processed meat samples to our surprise turn out to be the most challenging stage of dietNA characterization. Since there are no dedicated methods for dietNA isolation from food samples which can be processed in a variety of ways, we tested an array of commercially available kits recommended for NA isolation from difficult animal samples. These were (i) DNeasy Blood \& Tissue Kit, (Qiagen) for total DNA isolation from animal tissues and blood, (ii) ReliaPrep gDNA Tissue Miniprep System 
(Promega) for genomic DNA isolation from tissue, a buccal swab, or a mouse tail snip, and (iii) High Pure PCR Template Preparation Kit (Roche Life Science) for DNA isolation from a wide variety of sample materials, including whole blood, cultured cells, and tissue samples. In parallel, the classic isolation of NA by solvent extraction (phenol:chloroform:isoamyl alcohol $=25: 24: 1 \mathrm{v} / \mathrm{v} / \mathrm{v}$ ) was performed with and without RNase digestion or homogenization of samples under liquid nitrogen. According to our results (data not shown), the solvent extraction method proved to be the most efficient for isolation of DNA from samples homogenized in liquid nitrogen and enabled the isolation of the widest range of NA fragment lengths with the highest yield in comparison with commercially available, specialized isolation kits. This observation corresponds to the results obtained previously by other research groups (e.g., Turashvili et al. (2012), Özşensoy and Şahin (2016)). DNA fragment profiles and the purity and quantity of isolated NA have been determined and the obtained NA isolates were of acceptable purity and quantity (Table 1) for downstream processing.

The comparison of NA content isolated from raw and processed meat by solvent extraction shows that the extraction from heat-processed samples was twice more efficient (Table 1). This is not surprising as changes in protein structure due to thermal denaturation increase accessibility to proteinase $\mathrm{K}$ digestion used prior to isolation, which in turn makes NA easier to extract. The NA content determined by us for pig muscles amounted to about 2-3 mg per $1 \mathrm{~g} \mathrm{~d}$.w. and was lower than that reported earlier for DNA content in pig offal (6-17 mg/g d.w. according to Jonas et al. (2001)); however, offal are said to be a particularly rich source of dietary NA. It must be emphasized though, that neither those formerly published contents of dietNA nor our determinations can be regarded as truly precise. The capillary electrophoregrams obtained for NA isolates derived from three independent extractions of the same sample confirmed repeatability of the experimental procedure (Fig. 5a). However, the almost twofold difference in the NA content in dry mass of the sample between raw and boiled or cooked pork sirloin from the same portion of the meat undermines the reliability of the isolation method as a way of dietNA content determination. The comparison of capillary electrophoregrams for isolations with and without RNase digestion did not reveal any substantial changes in the NA size profiles (Fig. 5b); thus, probably the isolates contained only DNA as also suggested by experiments involving MGP staining.

\section{Electrophoretic Profiling of Isolated Nucleic Acids}

The results of comet assay suggested, that the substantial length variability of DNA fragments can be expected in meat samples studied. Should they be detected, also naturally occurring RNAs are of different lengths. Therefore, to precisely determine NA chain lengths in meat food samples studied, two methods - agarose gel and capillary electrophoresiswere compared. In the case of agarose gel electrophoresis ( $1 \%(\mathrm{w} / \mathrm{v})$ agarose), the NA chains up to $10,000 \mathrm{bp}$ could be separated and their length determined by comparison with the used molecular size marker (Fig. 6a). Longer fragments migrated slightly from or stayed at the loading point. The cartridges used for capillary electrophoresis enabled separation and quantification of NA fragments between 15 and 20,000 bp; longer NA were not separated from the latter. Owing to the use of known concentration of molecular size markers, quantitative analysis of separated NA fragments was also possible (Online Resource 1).

Figure $6 \mathrm{a}$ and $\mathrm{b}$ compares electrophoregrams and peak integration results obtained by the two techniques applied for NA isolates from raw, boiled, and grilled pork sirloin. The fragmentation patterns revealed by gel agarose and capillary electrophoresis are similar and demonstrated the substantial impact of processing on NA integrity, which most probably is DNA as the chain lengths expected for known RNAs (Storz 2020) are rather not represented in the electrophoregrams. In the case of unprocessed meat, one major broad band, though embracing wide range of DNA chain lengths that form a smear, was detected. This band well mirrors the short comet tails observed for this sample in comet assay. Such a band was

Table 1 Comparison of efficiency of DNA isolation from raw and processed meat by a dedicated kit or solvent-based extraction

\begin{tabular}{|c|c|c|c|c|c|c|}
\hline \multirow[t]{2}{*}{ Pork meat sample } & \multicolumn{3}{|l|}{ Solvent extraction } & \multicolumn{3}{|c|}{$\begin{array}{l}\text { DNA isolation commercial kit DNeasy Blood \& Tissue Kit } \\
\text { (Qiagen) }\end{array}$} \\
\hline & NA concentration $\mu \mathrm{g} / \mathrm{mL}$ & $A_{260} / A_{280}{ }^{\mathrm{a}}$ & NA content in meat $\mathrm{mg} / \mathrm{g}$ d.w. & NA concentration $\mu \mathrm{g} / \mathrm{mL}$ & $A_{260} / A_{280}{ }^{\mathrm{a}}$ & $\begin{array}{l}\text { NA content } \\
\text { in meat } \mathrm{mg} / \mathrm{g} \text { d.w. }\end{array}$ \\
\hline Raw & $88.65 \pm 3.48$ & $1.99 \pm 0.01$ & $2.62 \pm 0.09$ & $48.20 \pm 0.87$ & $1.99 \pm 0.02$ & $1.47 \pm 0.03$ \\
\hline Boiled & $160.48 \pm 16.31$ & $1.99 \pm 0.01$ & $3.37 \pm 0.41$ & $52.45 \pm 2.44$ & $1.98 \pm 0.01$ & $1.11 \pm 0.05$ \\
\hline Grilled & $171.68 \pm 6.89$ & $2.01 \pm 0.01$ & $3.36 \pm 0.17$ & $29.20 \pm 0.74$ & $1.93 \pm 0.10$ & $0.56 \pm 0.02$ \\
\hline
\end{tabular}

\footnotetext{
${ }^{\text {a }}$ NA purity assessed based on ratio of absorbance measured at $260 \mathrm{~nm}$ and $280 \mathrm{~nm}$ which for pure DNA equals to 1.8 for pure RNA to 2.0 . All measurements are given as means $\pm \mathrm{SD}$ from three independent determinations
} 
Fig. 5 Tests accompanying the NA profiling by capillary electrophoresis: (a) the overlaid capillary electrophoregrams obtained for separation of grilled pork meat nucleic acids derived from three independent isolations; (b) profiling of nucleic acids isolated from raw pork meat sample performed following isolation with or without the addition of RNase

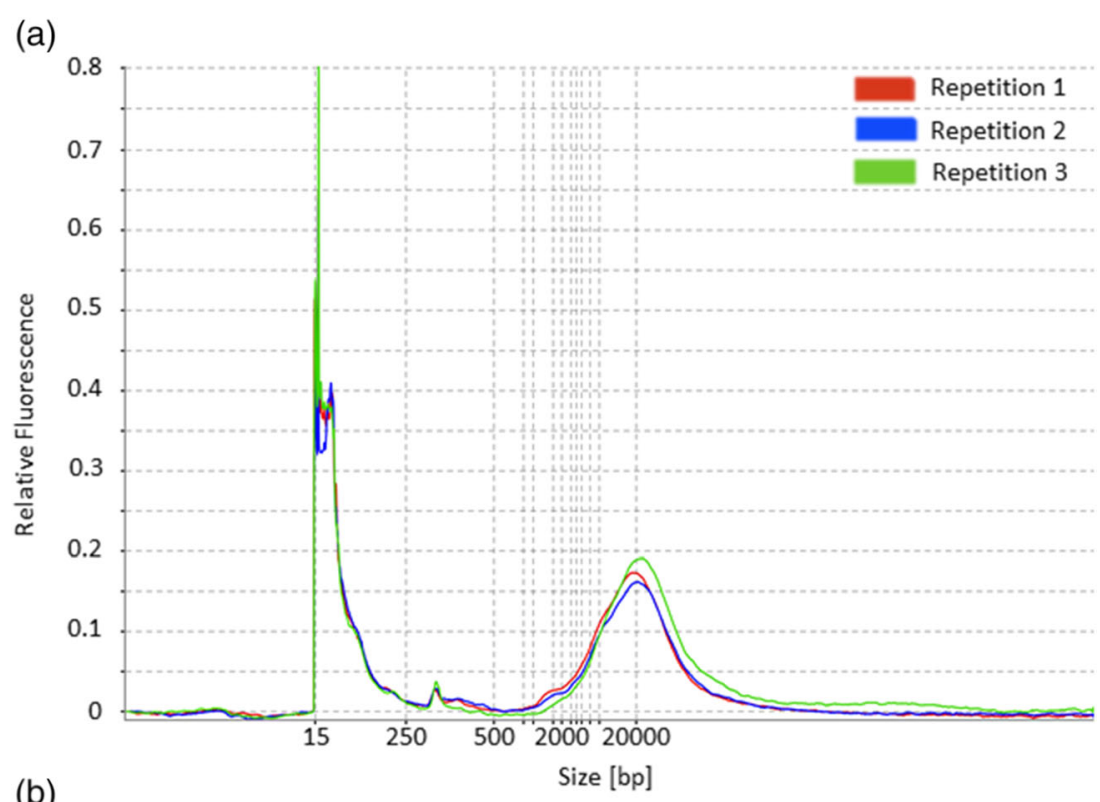

(b)

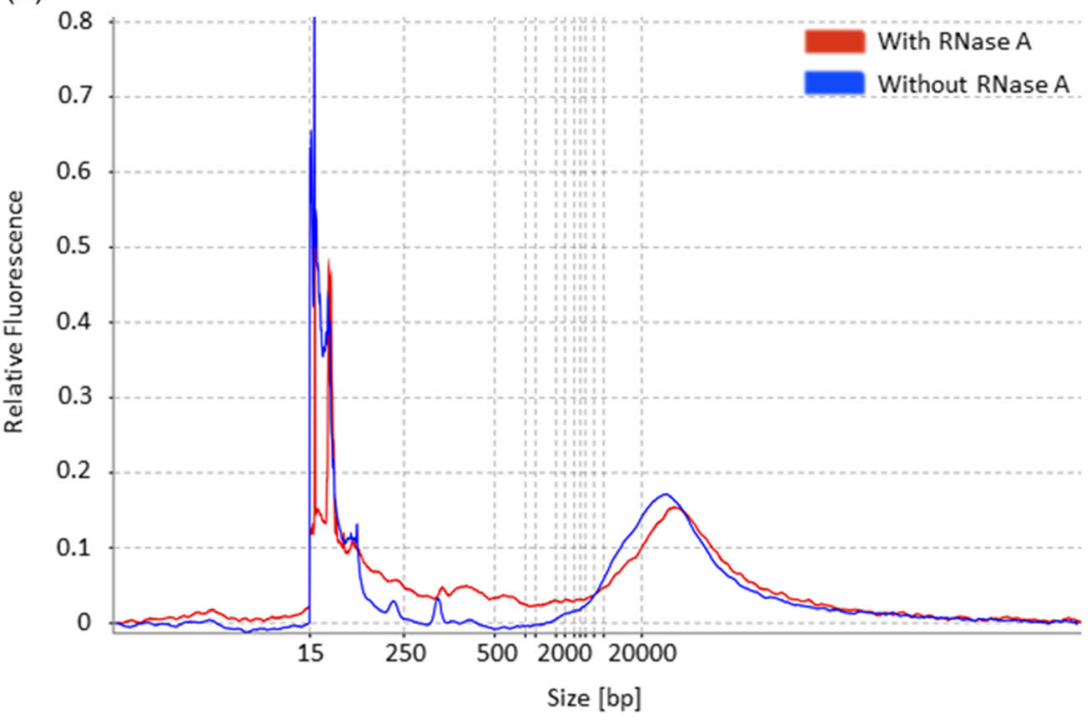

also observed in the grilled meat sample; however, in this case, it was also accompanied by a number of DNA bands with molecular weights falling in the range from 200 to $400 \mathrm{bp}$ (major band) and a few weak bands between 400 and 1000 bp. This again is in accord with comet assay results, where nuclei in the grilled meat sample had long tails containing heavily degraded DNA, but also well preserved heads enclosing high molecular weight DNA. The fragmentation pattern observed by both electrophoretic techniques applied for boiled in water meat sample was very surprising. In contrast to comet assay, where no comet tails were seen, DNA after isolation turned out to be heavily degraded into the broad spectrum of fragments with lengths below $400 \mathrm{bp}$. This result confirms our former supposition that boiling in water did not prevent chromatin degradation, but that nuclei became so compact that the DNA fragments could not migrate from them during electrophoresis. The low stability of NA in water environment when additionally heat treatment is applied, e.g., during steaming or in-water cooking, has been reported also by Bauer et al. (2003). In the case of all samples, NA isolates seemed to contain a substantial amount of short oligonucleotides (around $15 \mathrm{bp}$ ) detected in capillary electrophoresis.

\section{Discussion}

The research on DNA and RNAs, including food science field, is dominated by associating them almost exclusively with genetic information functions, where the most important feature of these molecules is the specific nucleotide sequence. This perspective however does not provide any insight into 
(a)

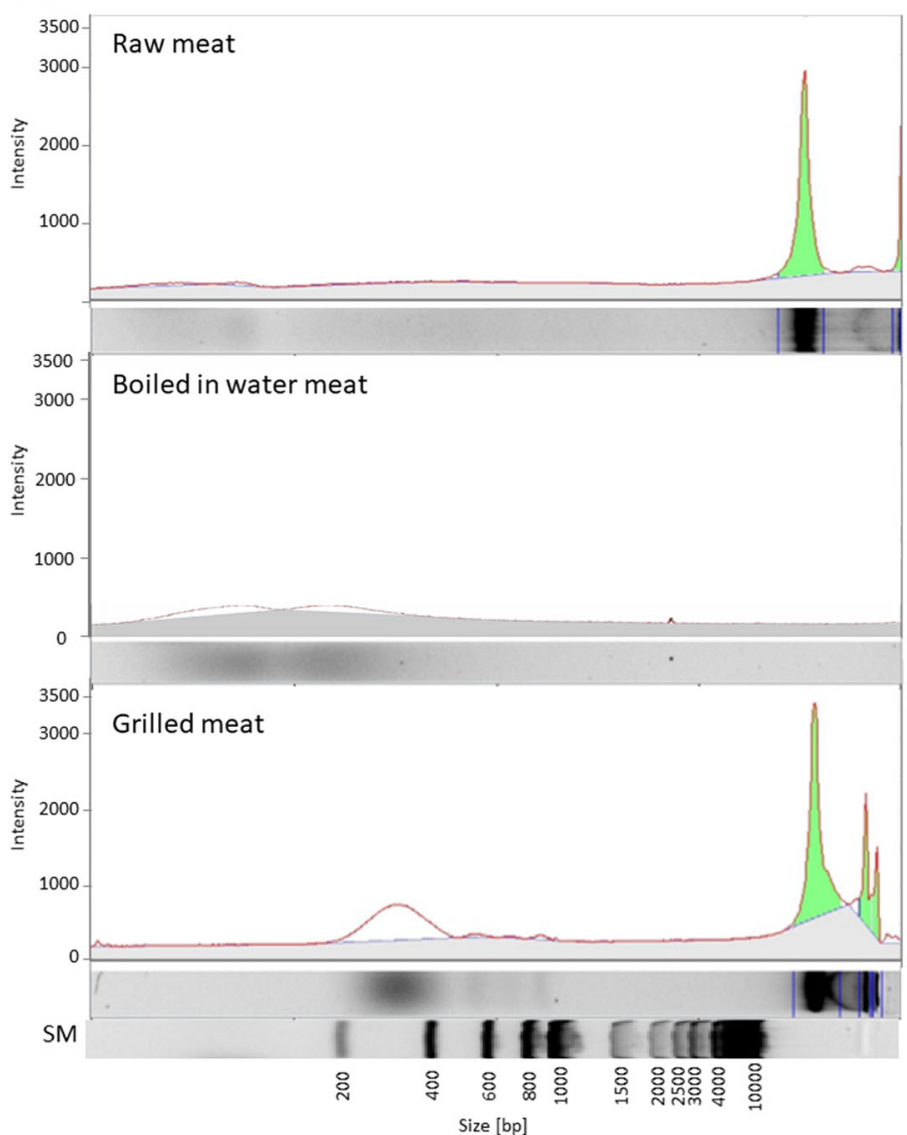

(b)

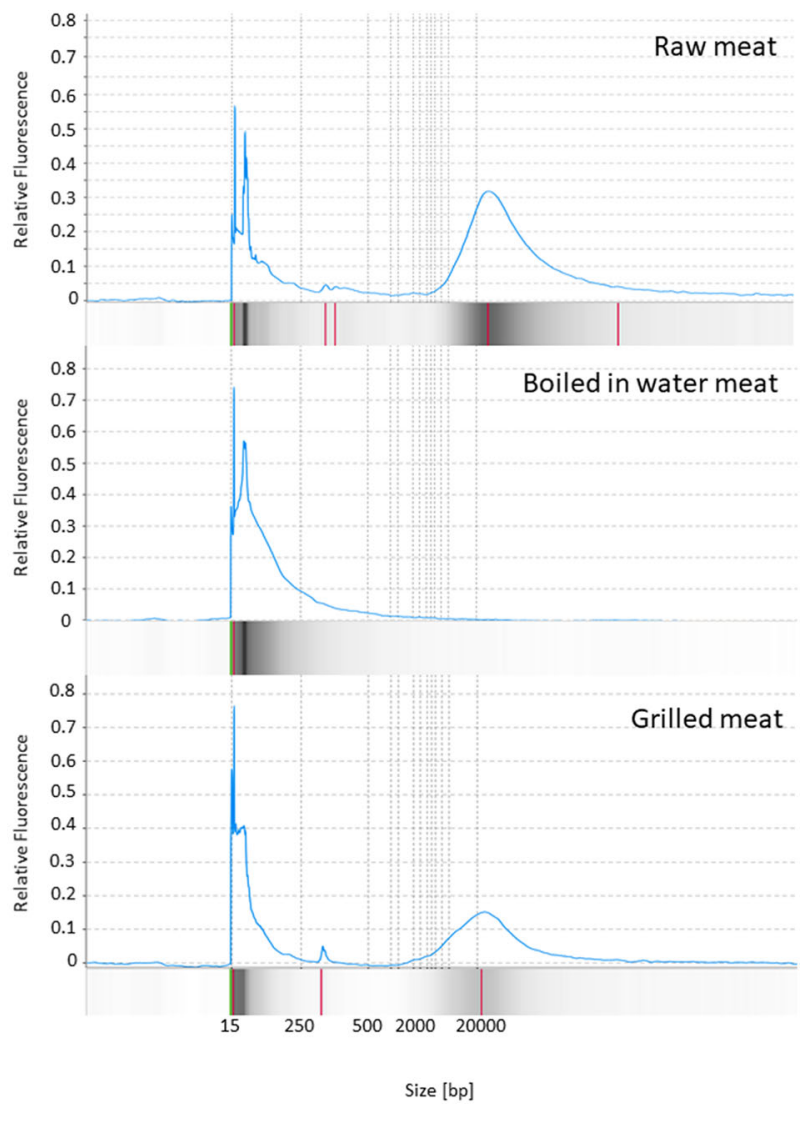

Fig. 6 The gel images for agarose electrophoresis separation and fragmentation profiles panel (a) and capillary electrophoresis panel (b) obtained for nucleic acids isolated from raw, boiled in water or grilled pork sirloin

the role of dietary nucleic acids (dietNA) as a chemical and nutritionally important food component, being e.g. a source of building blocks during replication or transcription as well as of nitrogen or phosphorus atoms needed in metabolism. Neither it considers the potential risks associated with the consumption of chemically altered dietNA, mainly oxidatively modified nucleobases, which with no doubt must arise in food, especially upon thermal processing (Bartoszek 2006). Nucleobases are reactive molecules and their stability in cells results from the existence of a number of protective mechanisms such as detoxification and antioxidative systems, DNA repair (Chatterjee and Walker 2017), and prevention of incorporation of damaged nucleobases during replication by MTH1 triphosphatases hydrolyzing triphosphates to monophosphates if a nucleobase is oxidatively modified (Fujikawa et al. 2001). In food, processed food in particular, it can be expected that all the mentioned protective barriers will not be fully operational, which means that dietNA will be no longer protected against oxygen reactivity, hence will contain chemically altered nucleotides. In general, the nutritional functions of dietNA, despite the fact that they are equally frequent food macromolecules as proteins, polysaccharides, or fats, have been so far underexplored in food sciences. The reason may be the lack of dedicated methodologies to characterize dietNA. In this study, using raw or processed meat products and raw edible plant parts as model foodstuffs, we developed a toolbox of methods, borrowed from other fields (histology, toxicology, molecular biology) that to our mind should enable the initial assessment of abundance and quality of dietNA as a necessary step on the way to systematic evaluation of their nutritional role.

The proposed set of methods embraces (i) paraffin embedding of food samples and their staining to visualize the distribution and variety of nucleic acids in situ; (ii) comet assay to assess the fragmentation of nuclear DNA with possible detection of DNA damage by comet shape; (iii) NA isolation with and without RNase digestion to determine the content of both DNA and RNA; and (iv) electrophoretic separation of isolates to profile NA fragments. Such a combined methodological approach proved to be suitable for characterization of dietNA from animal and plant samples, demonstrated clearly differences in dietNA derived from raw and processed meat products, but also revealed the shortages of the individual methods applied.

The paraffin-embedded tissues are routinely used in histological examinations for medicinal purposes, but this procedure has 
been also reported to be suitable for staining of milled raw meat tissue (Sadeghinezhad et al. 2016). In our hands, the differences in tissue structure due to water loss and shrinkage were easily recognizable after staining with basic histological dyes. Regardless of processing that caused degradation of NA as revealed by other techniques, in fixed preparations, the nuclei were well preserved and only DNA contained in nuclei was seen during microscope examination. Our observations were also in good correspondence with previous studies concerning MGP staining of paraffin-embedded samples ( $\mathrm{Li}$ et al. 2002), with the exception that no traces of RNA were visible after MGP staining. Probably this type of NA became degraded even before or during lengthy procedure of preparation of microscope slides. Therefore, furthermore, we concentrate on DNA as a representative of dietNA. Our study confirmed the usefulness of paraffinembedding technique for staining raw, but also thermally treated meat samples as well as raw plant samples, however the latter not always stained properly due to the interference from cell wall components. It is worthy to mention that alternative very recent technique of cryosectioning could prove even more suitable for the purpose of dietNA visualization in food samples. In this novel method, the tissue is immersed in the freezing medium and then, while still frozen, is cut into microscopic sections using a cryostat device. The sections are transferred onto a microscope slide and stained with appropriate dyes. The cryosectioning allows to obtain different tissue sections in much shorter time (few hours $v s$. few days), which may prevent RNA degradation. But this method is not only faster, it also minimizes morphological damage of the tissue. Therefore, cryostat sections are better for immunohistochemical staining than paraffin sections (Fischer et al. 2008; Hira et al. 2019). This may indicate that staining with fluorescent dyes that bind to NA will be also facilitated, which could be especially beneficial in the case of problematic plant food samples. We plan to compare the two mentioned techniques for the purpose of dietNA distribution analysis in the near future.

The evaluation of quantity and quality of dietDNA is a prerequisite to reason about their nutritional importance and to formulate dietary recommendations as well as to assess the safety of dietary supplements containing NA preparations. It would seem that the use of current standard methods of NA isolation should provide reliable results and enable the obtainment of highly purified polynucleotides with high yield. This turned out not to be the case and the array of commercially available methods seems rather designed to provide representative portions of NA suitable for subsequent amplification and sequencing than for quantitative purposes. Our study and the study of Turashvili et al. (2012) suggested that the solvent extraction procedures delivered NA of the highest purity with best extraction yields (Turashvili et al. 2012) and, importantly, as demonstrated by our experiments, could be applied also for processed food products. However, even with this technique, the quantitative recovery of NA was the most challenging step. On top of it, also the standard UV absorption measurements for concentration determination, i.e., NanoDrop measurements, are loaded with interferences. For these reasons, the isolation protocol of total NA as well as content determinations requires modifications to become a reliable quantitative method. Our current data on NA content (Table 1) must be thus regarded as rough estimates. Moreover, these estimates include neither very short (deoxy)oligonucleotides nor (deoxy)nucleotides that are not recovered by the solvent extraction technique applied, which nevertheless may be expected to occur in the food samples in substantial amounts as a result of e.g. RNA and DNA enzymatic hydrolysis or thermal degradation.

The assessment of dietNA quality in food samples studied, understood as DNA integrity, and the extent of polynucleotide degradation and chemical damage releasing fragmented DNA (under alkaline conditions of comet assay) proved much more successful. Although morphological examination of food tissues studied showed only intact nuclei, both comet assay and electrophoretic separation of NA isolates revealed substantial differences in quality of DNA in individual cells and NA isolates. In comet assay, reproductive parts of plants (bean seeds or potato tubers) turned out to contain DNA only little fragmented, while in animal myocytes and hepatocytes, the extent of DNA degradation was very high (Figs. 3 and 4). The heat processing, as revealed by comet assay and electrophoretic separation, considerably increased DNA degradation, which especially in the case of grilled meat could be even interpreted as DNA damage, because the comets acquired the shapes' characteristic for cells exposed to genotoxins (Rundell et al. 2003). In general, the both mentioned techniques lead to similar observations, however when combined provided more detailed information on the DNA quality; as mentioned before, we did not observed RNA in our food samples.

\section{Conclusions}

In conclusion, the toolbox of methods proposed in this paper makes it possible to initially characterize dietNA as regards their abundance, distribution in food tissue, the size of fragments, and indication of chemical DNA modification. Although cells have capacity of NA synthesis de novo, it seems highly improbable that dietNA are a food component which will not be extensively utilized as a nutrient whose biosynthesis is very costly for a cell, while requirement is very high. NA building blocks in different forms play a wide variety of roles in all organisms including humans. DietNA may be a source of monomers for synthesis of genomic and mitochondrial DNA as well as all kinds of coding and non-coding RNAs. Nucleotides are involved in energy transfer and are structural units of cofactors serving a variety of functions in metabolic pathways. The product of purine catabolism - uric acid — is an important antioxidant maintaining redox status of body fluids, and so on. However, chemically 
altered nucleobases may pose a mutagenic risk once incorporated into cellular NA that is currently not even taken under consideration in nutritional sciences. Therefore, we are convinced that dietNA should be more extensively studied in the nutrition and health context. At the moment, the reliable information about their quantity and characterization of their quality in raw and processed food products is lacking, while at the same time, the business of dietary supplements containing DNA is growing and is accompanied by several benefits claims not justified scientifically. We hope that the set of methods presented in our study, which enables the initial characterization in terms of morphology, integrity, fragmentation profile, and the impact of processing on these features, will encourage the research on dietNA as a food component. Importantly, to make such investigations of real value, good and reproducible isolation methods from difficult samples such as culinary treated and/or heat-processed foods for precise quantitative analysis will have to be elaborated.

Supplementary Information The online version contains supplementary material available at https://doi.org/10.1007/s12161-021-01988-4.

Acknowledgements The authors would like to thank Mrs Anna Beszczyńska from the Department of Histology, Medical University of Gdansk for her assistance during preparation of paraffin blocks and Prof. Małgorzata Kozieradzka-Kiszkurno and co-workers from University of Gdansk, Faculty of Biology, for the patient guidance during preparation of microscope slides. Great thanks go also to two undergraduate students Urszula Stankiewicz and Wiktoria Ćwiklińska who realized their MSc projects under Agnieszka Bartoszek supervision for their deep engagement in experimental studies.

\section{Code Availability Not applicable.}

Author Contributions Conceptualization: Joanna Cieślewicz and Agnieszka Bartoszek. Data curation: Joanna Cieślewicz and Zuzanna Koziara. Formal analysis: Joanna Cieślewicz. Funding acquisition: Joanna Cieślewicz. Investigation: Joanna Cieślewicz, Zuzanna Koziara, and Wiktoria Ćwiklińska. Methodology: Joanna Cieślewicz, Zuzanna Koziara, Wiktoria Ćwiklińska, and Agnieszka Bartoszek. Project administration: Joanna Cieślewicz and Agnieszka Bartoszek. Supervision: Agnieszka Bartoszek. Validation: Joanna Cieślewicz, Zuzanna Koziara, and Agnieszka Bartoszek. Visualization: Joanna Cieślewicz, Zuzanna Koziara, and Agnieszka Bartoszek. Writing - original draft: Joanna Cieślewicz, Zuzanna Koziara, and Agnieszka Bartoszek. Writingreview and editing: Joanna Cieślewicz, Zuzanna Koziara, and Agnieszka Bartoszek. All authors have read and agreed to the published version of the manuscript.

Funding This study was funded by The National Science Centre, Poland (grant number 2016/23/N/NZ9/02227) in a Programme Preludium 12.

Data Availability Not applicable.

\section{Declarations}

Ethics Approval This article does not contain any results from studies involving human participants or animals performed by any of the authors.

Consent to Participate Not applicable.
Consent for Publication Not applicable.

Conflict of Interest Joanna Cieślewicz declares that she has no conflict of interest. Zuzanna Koziara declares that she has no conflict of interest. Wiktoria Ćwiklińska declares that she has no conflict of interest. Agnieszka Bartoszek declares that she has no conflict of interest.

Open Access This article is licensed under a Creative Commons Attribution 4.0 International License, which permits use, sharing, adaptation, distribution and reproduction in any medium or format, as long as you give appropriate credit to the original author(s) and the source, provide a link to the Creative Commons licence, and indicate if changes were made. The images or other third party material in this article are included in the article's Creative Commons licence, unless indicated otherwise in a credit line to the material. If material is not included in the article's Creative Commons licence and your intended use is not permitted by statutory regulation or exceeds the permitted use, you will need to obtain permission directly from the copyright holder. To view a copy of this licence, visit http://creativecommons.org/licenses/by/4.0/.

\section{References}

Adjei AA, Yamamoto S, Kulkarni A (1995) Nucleic acids and/or their components: a possible role in immune function. J Nutr Sci Vitaminol 41:1-16. https://doi.org/10.3177/jnsv.41.1

Arslan A, Ilhak OI, Calicioglu M (2006) Effect of method of cooking on identification of heat processed beef using polymerase chain reaction (PCR) technique. Meat Sci 72:326-330. https://doi.org/10. 1016/j.meatsci.2005.08.001

Bartoszek A (2006) Genotoxic food components. In: Baer-Dubowska W, Bartoszek A, Malejka-Giganti D (eds) Carcinogenic and Anticarcinogenic Food Components. CRC Press LLC, Boca Raton, pp 69-96

Bauer T, Weller P, Hammes WP (2003) The effect of processing parameters on DNA degradation in food. Eur Food Res Technol 217:338 343. https://doi.org/10.1007/s00217-003-0743-y

Carver JD (1999) Dietary nucleotides: effects on the immune and gastrointestinal systems. Acta Paediatr Suppl 88:83-88. https://doi.org/10. 1111/j.1651-2227.1999.tb01306.x

Carver JD, Walker AW (1995) The role of nucleotides in human nutrition. J Nutr Biochem 6:58-72. https://doi.org/10.1016/09552863(94)00019-I

Cedra H (1998) Detection of irradiated fresh chicken, pork and fish using the DNA comet assay. Leb und-Technologie 31:89-92. https://doi. org/10.1006/fstl.1997.0304

Chatterjee N, Walker GC (2017) Mechanisms of DNA damage, repair, and mutagenesis. Environ Mol Mutagen 58:235-263. https://doi. org $/ 10.1002 / \mathrm{em} .22087$

Delincée H, Pool-Zobel B-L (1998) Genotoxic properties of 2dodecylcyclobutanone, a compound formed on irradiation of food containing fat. Radiat Phys Chem 52:39-42. https://doi.org/10. 1016/S0969-806X(98)00070-X

Doare KL, Holder B, Bassett A, Pannaraj PS (2018) Mother's milk: a purposeful contribution to the development of the infant microbiota and immunity. Front Immunol 9. https://doi.org/10.3389/fimmu. 2018.00361

Ferrari CDS, Valente LL, Brod FCA et al (2007) Evaluation of polymerase chain reaction and DNA isolation protocols for detection of genetically modified soybean. Int J Food Sci Technol 42:1249 1255. https://doi.org/10.1111/j.1365-2621.2006.01405.x

Fischer AH, Jacobson KA, Rose J, Zeller R (2008) Cryosectioning tissues. Cold Spring Harb Protoc 3:1-2. https://doi.org/10.1101/pdb. prot 4991 
Fujikawa K, Kamiya H, Yakushiji H et al (2001) Human MTH1 protein hydrolyzes the oxidized ribonucleotide, 2-hydroxy-ATP. Nucleic Acids Res 29:449-454. https://doi.org/10.1093/nar/29.2.449

Głazowska J, Stankiewicz U, Bartoszek A (2017) Absorpcja, metabolizm i rola biologiczna kwasów nukleinowych obecnych w żywności. Żywność Nauk Technol Jakość 110:18-32. https://doi.org/10. 15193/zntj/2017/110/170

Głazowska J, Stankiewicz U, Tylingo R, Bartoszek A (2016) Kwasy nukleinowe w żywności: występowanie i właściwości funkcjonalne. Żywność Nauk Technol Jakość 109:5-19. https://doi.org/10.15193/ zntj/2016/109/157

Herbel W, Montag A (1987) Nucleostoffe in Proteinreichen Lebensmitteln. Z Lebensm Unters Forch 185:119-122. https://doi. org/10.1007/BF01850090

Herman L, De Block J, Viane R (2003) Detection of hazelnut DNA traces in chocolate by PCR. Int J Food Sci Technol 38:633-640. https:// doi.org/10.1046/j.1365-2621.2003.00722.x

Hess JR, Greenberg NA (2012) The role of nucleotides in the immune and gastrointestinal systems potential clinical applications. Nutr Clin Pract 27:281-294. https://doi.org/10.1177/0884533611434933

Hira VVV, de Jong AL, Ferro K et al (2019) Comparison of different methodologies and cryostat versus paraffin sections for chromogenic immunohistochemistry. Acta Histochem 121:125-134. https:// doi.org/10.1016/j.acthis.2018.10.011

Imafidon GI, Sosulski FW (1990) Nucleic acid nitrogen of animal and plant foods. J Agric Food Chem 38:118-120. https://doi.org/10. 1021/jf00091a024

Jakubek P, Cieślewicz J, Bartoszek A (2020) MicroRNAs as novel bioactive components of human breastmilk. Postepy Hig Med Dosw 74:103-115. https://doi.org/10.5604/01.3001.0014.1434

Jonas DA, Elmadfa I, Engel K-H et al (2001) Safety considerations of DNA in food. Ann Nutr Metab 45:235-254. https://doi.org/10. $1159 / 000046734$

Khan AA, Khan HM (2008) DNA comet assay: a simple screening technique for identification of some irradiated foods. J Radioanal Nucl Chem 275:337-342. https://doi.org/10.1007/s10967-007-7068-4

Lassek E, Montag A (1990) Nucleostoffe in Kohlenhydratreichen Lebensmitteln. Z Lebensm Unters Forch 190:17-21. https://doi. org/10.1007/BF01188257

Li B, Wu Y, Gao XM (2002) Pyronin Y as a fluorescent stain for paraffin sections. Histochem J 34:299-303. https://doi.org/10.1023/A: 1023325213198

Manzano M, Abadía-Molina AC, Olivares EG et al (2003) Dietary nucleotides accelerate changes in intestinal lymphocyte maturation in weanling mice. J Pediatr Gastroenterol Nutr 37:453-461. https://doi. org/10.1097/00005176-200310000-00010

Marín-Huachaca N, Delincée H, Mancini-Filho J, Villavicencio ALCH (2005) Use of the DNA comet assay to detect beef meat treated by ionizing radiation. Meat Sci 71:446-450. https://doi.org/10.1016/j. meatsci.2005.04.019

Melnik BC, Schmitz G (2017) MicroRNAs: milk's epigenetic regulators. Best Pract Res Clin Endocrinol Metab 31:427-442. https://doi.org/ 10.1016/j.beem.2017.10.003

Meyer R, Chardonnens F, Hübner P, Lüthy J (1996) Polymerase chain reaction (PCR) in the quality and safety assurance of food: detection of soya in processed meat products. Z Lebensm Unters Forsch 203: 339-344. https://doi.org/10.1007/BF01231072

Nakamoto M, Shuto E, Hosaka T, Sakai T (2011) Dietary deoxynucleic acid induces type $2 \mathrm{~T}$-helper immune response through toll-like receptor 9 in mice. Eur J Nutr 50:421-426. https://doi.org/10. 1007/s00394-010-0153-4

Özșensoy Y, Șahin S (2016) Comparison of different DNA isolation methods and use of dodecyle trimethyl ammonium bromide (DTAB) for the isolation of DNA from meat products. J Adv Vet Anim Res 3:368-374. https://doi.org/10.5455/javar.2016.c175
Pourrut B, Pinelli E, Celiz Mendiola V et al (2014) Recommendations for increasing alkaline comet assay reliability in plants. Mutagenesis 30: 37-43. https://doi.org/10.1093/mutage/geu075

Rundell MS, Wagner ED, Plewa MJ (2003) The comet assay: genotoxic damage or nuclear fragmentation? Environ Mol Mutagen 42:61-67. https://doi.org/10.1002/em.10175

Sadeghinezhad J, Hajimohammadi B, Izadi F et al (2016) Evaluation of the morphologic method for the detection of animal and herbal content in minced meat. Czech J Food Sci 33:564-569. https://doi.org/ 10.17221/167/2015-CJFS

Scaravelli E, Brohée M, Marchelli R, Van Hengel AJ (2008) Development of three real-time PCR assays to detect peanut allergen residue in processed food products. Eur Food Res Technol 227:857869. https://doi.org/10.1007/s00217-007-0797-3

Schubbert R, Hohlweg U, Renz D, Doerfler W (1998) On the fate of orally ingested foreign DNA in mice : chromosomal association and placental transmission to the fetus. Mol Gen Genomics 259: 569-576. https://doi.org/10.1007/s004380050850

Storz G (2020) An expanding universe of noncoding RNAs. Science 296: 1260-1263. https://doi.org/10.1126/science.1072249

Straub JA, Hertel C, Hammes WP (1999) The fate of recombinant DNA in thermally treated fermented sausages. Eur Food Res Technol 210: 62-67. https://doi.org/10.1007/s002170050534

Tanabe S, Miyauchi E, Muneshige A et al (2007) PCR method of detecting pork in foods for verifying allergen labeling and for identifying hidden pork ingredients in processed foods. Biosci Biotechnol Biochem 71:1663-1667. https://doi.org/10.1271/bbb.70075

Turashvili G, Yang W, McKinney S et al (2012) Nucleic acid quantity and quality from paraffin blocks: defining optimal fixation, processing and DNA/RNA extraction techniques. Exp Mol Pathol 92:3343. https://doi.org/10.1016/j.yexmp.2011.09.013

Van Der Colff L, Podivinsky E (2008) Cooking DNA: The effect of 'domestic' cooking methods on detection of GM potato. Int $\mathrm{J}$ Food Sci Technol 43:2105-2112. https://doi.org/10.1111/j.13652621.2008.01739.x

Weigel D, Glazebrook J (2008) Fixation, embedding, and sectioning of plant tissues. Cold Spring Harb Protoc 2008:pdb.prot4941. https:// doi.org/10.1101/pdb.prot4941

Witwer KW, Hirschi KD (2014) Transfer and functional consequences of dietary microRNAs in vertebrates: concepts in search of corroboration. Bioessays 36:394-406. https://doi.org/10.1002/bies.201300150

Witwer KW, Zhang C-Y (2017) Diet-derived microRNAs: unicorn or silver bullet ? Genes Nutr 15:13-16. https://doi.org/10.1186/ s12263-017-0564-4

Xu M, Liang R, Li Y, Wang J (2017) Anti-fatigue effects of dietary nucleotides in mice. Food Nutr Res 61:1334485. https://doi.org/ 10.1080/16546628.2017.1334485

Yang J, Elbaz-Younes I, Primo C, Murungi D, Hirschi KD (2018) Intestinal permeability, digestive stability and oral bioavailability of dietary small RNAs. Sci Rep 8:10253. https://doi.org/10.1038/ s41598-018-28207-1.

Yao X, Zhong L (2005) Genotoxic risk and oxidative DNA damage in HepG2 cells exposed to perfluorooctanoic acid. Mutat Res Toxicol Environ Mutagen 587:38-44. https://doi.org/10.1016/j.mrgentox. 2005.07.010

Zhang L, Hou D, Chen X et al (2012) Exogenous plant MIR168a specifically targets mammalian LDLRAP1: evidence of cross-kingdom regulation by microRNA. Cell Res 22:107-126. https://doi.org/10. $1038 /$ cr.2011.158

Publisher's Note Springer Nature remains neutral with regard to jurisdictional claims in published maps and institutional affiliations. 